\title{
Characterization of Oaxaca raw milk cheese microbiota with particular interest in Lactobacillus strains
}

\author{
Irma Caro, ${ }^{* 1}$ Javier Mateo, ${ }^{*} †$ María H. Sandoval, ${ }^{*}$ Sergio Soto,ł María R. García-Armesto, ${ }^{*}$ \\ and José M. Castroł§ \\ *Department of Food Hygiene and Food Technology, University of León, Campus de Vegazana s/n, C.P. 24071 León, Spain \\ †Instituto de Ciencia y Tecnología de los Alimentos, University of León, La Serna, 56, C.P., 24007 León, Spain \\ $\ddagger$ Research Center of Food Science and Technology, University of Hidalgo State, C.P. 43600 Tulancingo, Hidalgo, México \\ §Department of Molecular Biology, University of León, 24071 León, Spain
}

\begin{abstract}
The aim of this work was to identify and characterize lactobacilli strains from Mexican Oaxaca cheese. Twenty-seven lactobacilli isolated from Oaxaca cheese were identified at species level by $16 \mathrm{~S}$ rRNA sequencing. Selected isolates were further characterized by ribotyping. Isolates were screened, among others, by acidifying capacity, antibiotic resistance, and activity against pathogens. Lactobacillus plantarum was predominant in Oaxaca cheese. The intraspecies variability of $L b$. plantarum isolates was great. Multiple antibiotic resistances were observed. Eight isolates showed antimicrobial activity against the pathogenic species tested. Four Lb. plantarum strains showing low antibiotic resistance index, antimicrobial activity against enterotoxigenic Staphylococcus aureus and Listeria innocua stains, amine-negative decarboxylase activity, and resistance to $\mathrm{NaCl}$ and bile salt solutions, could be preselected to complete studies focused on designing a culture for use in pasteurized-milk Oaxaca cheese manufacturing.
\end{abstract}

Key words: lactobacilli, antibiotic resistance, Mexican cheese, starter culture

\section{INTRODUCTION}

Oaxaca cheese is one of the most popular cheeses in Mexico (Villanueva-Carvajal et al., 2012). It is a pasta filata cheese normally produced from raw milk when manufactured at small dairy plants (Domínguez-López et al., 2011). The acidification process of the curd is a key point of the Oaxaca cheese-making process. It usually takes from 4 to $8 \mathrm{~h}$ and a strict control of the $\mathrm{pH}$ decline of the curd at 35 to $38^{\circ} \mathrm{C}$ (to a $\mathrm{pH}$ of approximately 5.3) is required, in order to obtain the characteristic fibrous curd straps by kneading and stretching

Received August 30, 2012.

Accepted February 20, 2013.

${ }^{1}$ Corresponding author: icarc@unileon.es of the acidified curd in hot water (Aguilar-Uscanga et al., 2006).

The presence of lactobacilli in cheese is common. Lactobacilli are an important part of the nonstarter lactic acid bacteria (LAB) and can contribute to cheese flavor and texture (Khalid and Marth, 1990). The nonstarter lactobacilli most frequently isolated from cheese are facultatively heterofermentative (Beresford et al., 2001). These microorganisms appear to be predominant in the microbiota of the intensively acidified cheese curds due to their ability to grow at low $\mathrm{pH}$ (Sánchez et al., 2005). Lactobacilli species from cheeses have been identified on the basis of phenotypic and genotypic characteristics (Kongo et al., 2007).

The presence of antibiotic resistance genes in many $\mathrm{LAB}$ and the transfer of genetic resistance determinants to and from other LAB is a well-known fact (Mathur and Singh, 2005). Starter cultures can serve as a means of transmission of such genes. Knowledge on natural resistance for particular Lactobacillus species increases the safety of the products via implementation of an increased monitoring of antibiotic resistance of starter cultures.

To our knowledge, several aspects of Oaxaca cheese quality have been previously studied (De Oca-Flores et al., 2009; Caro et al., 2011; de los Ángeles Colín-Cruz et al., 2012). However, no scientific information is available on its microbiology. The knowledge of the LAB, mainly lactobacilli, involved in the elaboration of this cheese would be of great interest to obtain not only a real picture of its quality but also a proper and safe starter culture to be used for pasteurized milk Oaxaca cheese making. The development of standardized procedures for the elaboration of this cheese using well-defined and appropriate starters is of obvious importance. This study, therefore, was aimed at the identification and the characterization of lactobacilli isolates present in Oaxaca cheese made from raw milk, which could be taken into consideration to select the proper strains for a suitable starter culture for the manufacturing of this cheese. 


\section{MATERIALS AND METHODS}

\section{Cheese Samples and Microbiological Analyses}

Eight samples of traditionally made Oaxaca cheese made with raw milk were purchased directly from the correspondent $(\mathrm{n}=8)$ local cheese plants in Valle de Tulancingo (Hidalgo, Mexico). Cheese samples weighing 200 to $500 \mathrm{~g}$ were transported for up to $1 \mathrm{~h}$ from the cheese plant to the laboratory inside their original packages, where they remained at $4^{\circ} \mathrm{C}$ for up to $6 \mathrm{~h}$ before analysis. From each sample, a 10-g aliquot was aseptically obtained by means of radial cuts (IDF, 1995a) and homogenized in $90 \mathrm{~mL}$ of buffered peptone water (CM 509; Oxoid Ltd., Basingstoke, UK), according to methods of the International Dairy Federation (IDF, 1996) with a Stomacher 400 circulator (Seward Ltd., London, UK) for $2 \mathrm{~min}$. Duplicate serial dilutions were prepared in buffered peptone water and then $1 \mathrm{~mL}$ of each dilution was plated on specific media. Aerobic mesophilic bacteria were grown on plate count agar (Difco Laboratories Inc., Detroit, MI) at $32^{\circ} \mathrm{C}$ for $48 \mathrm{~h}$; molds and yeast on potato dextrose agar (Oxoid Ltd.), acidified using $10 \%$ tartaric acid to $\mathrm{pH} 3.5$ at $22^{\circ} \mathrm{C}$ for $7 \mathrm{~d}$; $\mathrm{LAB}$ on de Man, Rogosa, and Sharpe (MRS) agar (Oxoid Ltd.), adjusted to $\mathrm{pH} 5.5$ with lactic acid, under anaerobiosis at $37^{\circ} \mathrm{C}$ for $48 \mathrm{~h}$; and Escherichia coli and coliforms were enumerated on $3 \mathrm{M}$ Petrifilm E. coli/coliform (3M Microbiology, St. Paul, MN), at $37^{\circ} \mathrm{C}$ for 24 to $48 \mathrm{~h}$.

\section{Lactobacilli Isolation and Basic Characterization}

Ten colonies per sample were randomly picked from MRS agar plates, reaching a total of 160 . These isolates were then grown in MRS broth (Oxoid Ltd.) at $37^{\circ} \mathrm{C}$ overnight. A total of $800 \mu \mathrm{L}$ of broth was then mixed with $200 \mu \mathrm{L}$ of glycerol and the mixture was stored at $-80^{\circ} \mathrm{C}$ until further use. Afterward, the stored isolates were grown at $30^{\circ} \mathrm{C}$ on MRS broth (Oxoid Ltd.) and then a loopful of growth was subcultured in MRS agar. From this, basic characterization of the isolates was performed through Gram reaction, morphology, and catalase $\left(\mathrm{H}_{2} \mathrm{O}_{2}, 3 \% \mathrm{vol} / \mathrm{vol}\right)$ and cytochrome-oxidase activities according to Harrigan (1998).

\section{Genotypic Identification}

Polymerase chain reaction amplification and DNA sequence analysis were performed on 27 isolates randomly chosen from the MRS isolates identified as lactobacilli $(\mathrm{n}=79)$ according to a basic characterization test. Isolates were grown on MRS plates for $48 \mathrm{~h}$ at $37^{\circ} \mathrm{C}$ before analysis. Methods and conditions of the identification were those described by González et al. (2007). The oligonucleotide primers used were as follows: forward primer 515 FPL: 5'CGGATCCTCTAGACTGCAGTGCCAGCAGCCGCGGTAA3' and reverse primer 13B: 5'CGGGATCCCAGGCCCGGGAACGTATTCAC3', yielding a product of $904 \mathrm{bp}$, and forward primer 9IE: 5'GGAATTCAAAKGAATTGACGGGGGC3' and reverse primer 13B, giving a product of $475 \mathrm{bp}$. These were obtained from Amersham Pharmacia Biotech Inc. (Piscataway, NJ) and described by Relman (1993). The PCR fragments were purified with Montage PCR centrifugal filter devices from Millipore Corp. (Billerica, MA) and then sequenced directly. Sequencing was performed using the DYEnamic ET Dye Terminator Kit and MEGABACE 500 DNA Analysis System (GE Healthcare Life Sciences, Piscataway Township, NJ). Fluorograms were analyzed with the sequencing software Chromas 2.23 (Technelysium Pty Ltd., Helensvale, Australia), which opens chromatogram files produced by Applied Biosystems Inc. (Foster City, CA) equipment and exports sequences in plain text, formatted with base numbering, FASTA format, or EMBL format. The sequences obtained were then sent to the National Centre for Biotechnology Information (NCBI) to be analyzed for the nucleotide-nucleotide BLAST database (http://blast.ncbi.nlm.nih.gov/) in FASTA format (http://www.ebi.ac.uk/Tools/fasta33/genomes. html) and $16 \mathrm{~S}$ ribosomal database (http://rdp.cme. msu.edu/seqmatch/seqmatch_intro.jsp).

Furthermore, an automated DuPont RiboPrinter Microbial Characterization System (Qualicon Inc., Wilmington, DE) was used to provide additional information on the identifications obtained by $16 \mathrm{~S}$ rRNA sequencing. Briefly, 20 out of the $27 \mathrm{MRS}$ lactobacilli isolates were grown on MRS plates for $48 \mathrm{~h}$ at $37^{\circ} \mathrm{C}$. For each plate, a loopful of the growth was suspended in the sample buffer recommended by the manufacturer, inactivated by a heat kill step, treated with lytic enzymes to release the DNA, and then cut with the restriction endonuclease EcoRI at $37^{\circ} \mathrm{C}$ for $20 \mathrm{~min}$. Fragments once separated by electrophoresis were transferred to a nylon membrane. A DNA probe for the E. coli $r r n \mathrm{~B}$ operon was then hybridized to the genomic DNA on the membrane. The genetic fingerprint was visualized and captured using a chemiluminescent detection module and a digitizing camera provided with the aforementioned RiboPrinter System. The analysis software automatically characterized and identified the digitalized image. Each clone was identified using the comparison of the RiboPrint pattern with an identification database of EcoRI RiboPrint patterns created by E. I. DuPont de Nemours and Company (Qualicon, Wilmington, DE).

\section{Phenotypic Characterization}

The 27 isolates identified were tested for resistance to antibiotics (BBL Sensi-Disc; Becton Dickinson, Cock- 
eysville, MD). The antibiotics were penicillin $\mathrm{G}(10 \mu \mathrm{g})$, ampicillin $(25 \mu \mathrm{g})$, cefsulodin $(30 \mu \mathrm{g})$, cefoxitin $(30 \mu \mathrm{g})$, and amoxicillin/clavulanic acid $(20 / 10 \mu \mathrm{g})$, belonging to group I $(\beta$-lactam); bacitracin $(10 \mu \mathrm{g})$, vancomycin $(30 \mu \mathrm{g})$, and doxycycline $(30 \mu \mathrm{g})$ from group II (non$\beta$-lactam cell wall); streptomycin $(300 \mu \mathrm{g})$, tetracycline $(30 \mu \mathrm{g})$, clindamycin $(10 \mu \mathrm{g})$, kanamycin $(30 \mu \mathrm{g})$, and neomycin $(30 \mu \mathrm{g})$, from group III (inhibit protein or mRNA synthesis); nalidixic acid $(30 \mu \mathrm{g})$, norfloxacin $(10 \mu \mathrm{g})$, metronidazole $(80 \mu \mathrm{g})$, belonging to group IV (DNA gyrase or DNA synthesis, or both); and finally, trimethoprim $(5 \mu \mathrm{g})$, trimethoprim-sulfamethoxazole $(1.25 \mu \mathrm{g} / 23.75 \mu \mathrm{g})$, and polymyxin B $(300 \mu \mathrm{g})$ belonging to group $\mathrm{V}$ (antimetabolites and cell membrane disruption, respectively). Sensitivity was determined using the agar diffusion method, as recommended by the National Committee for Clinical Laboratory Standards (NCCLS, 1997) according to the manufacturers. Analyses were carried out on Mueller-Hinton agar (MHA; Oxoid Ltd.). Four antibiotics discs were placed on the plates and after incubation $\left(37^{\circ} \mathrm{C}\right)$ the diameter of the inhibition zones was measured.

Antimicrobial activity assays against Staphylococcus aureus (strains S13, 5192), Bacillus cereus (PI-1), and Listeria innocua (125) were carried out. Foodborne pathogens from these genera or species are safety issue concerns in the dairy industry. Strains S13 and 125 were supplied by the Department of Food Hygiene and Food Technology, University of León (León, Spain), and those of PI-1 and 5192 by the Hannah Research Institute (Ayr, UK) and the Colección Española de Cultivos Tipo (CECT; Valencia, Spain), respectively. The tests were carried out in nutrient agar (Merck KGaA, Darmstadt, Germany), using the standard method described by Shahani et al. (1976).

Additional phenotypic characteristics were determined with the Vitek Automated Identification System (bioMérieux, Marcy l'Étoile, France), using a grampositive identification card. Additional tests were also carried out; these included growth in $6 \% \mathrm{NaCl}$, pyruvate fermentation, and motility at $30^{\circ} \mathrm{C}$. Moreover, the acidifying activity of strains was measured according to the International Dairy Federation Standard 306 (IDF, 1995b). The strains were subcultured in MRS broth supplemented with $0.006 \%$ yeast extract (Oxoid Ltd.) at $30^{\circ} \mathrm{C}$ for $24 \mathrm{~h}$. The microbial culture was inoculated at $1 \%(\mathrm{vol} / \mathrm{vol})$ in sterile skim power milk (reconstituted at $100 \mathrm{~g} / \mathrm{L}$ ) in duplicate and $\mathrm{pH}$ values were measured after 6,12 , and $24 \mathrm{~h}$ of incubation at $30^{\circ} \mathrm{C}$. Furthermore, their ability to grow at 15 and $45^{\circ} \mathrm{C}$ in MRS broth was tested.

\section{RESULTS}

\section{Microbiological Counts and Basic Characterization of Isolates}

Mean counts of microbial groups in the 8 Oaxaca cheeses sampled are given in Table 1 . Counts were relatively uniform for aerobic mesophilic, psychrotrophic bacteria, and LAB, but diverse for the other groups, chiefly for molds and yeasts where counts ranged from as low as $0.15\left(\log _{10} \mathrm{cfu} / \mathrm{g}\right)$ to as high as 6.25 (data not shown in tables).

Almost 50\% (79 out of 160) of the isolates from MRS plates, on the basis of their cell morphology and showing to be gram positive, catalase negative, and oxidase negative, were identified presumptively as lactobacilli. From them, 27 randomly chosen isolates were subject to further identification and characterization studies.

\section{Genotypic Identification}

Most of the 27 isolates tested were shown to be Lactobacillus plantarum by means of $16 \mathrm{~S}$ rRNA gene sequencing (21 out of 27; Figure 1). The other 6 were identified as Lactobacillus brevis $(\mathrm{n}=3)$, Lactobacillus sakei $(\mathrm{n}=2)$, and Lactobacillus paracasei $(\mathrm{n}=1)$. The 3 isolates identified as $L b$. brevis were initially ambiguously identified as $L b$. plantarum/Lb. brevis.

The ribotyping performance is also shown in Figure 1. From the 20 lactobacilli isolates subjected to genetic identification by ribotyping, only 18 showed valid results. The other 2 isolates could not be identified by ribotyping, but were identified as $L b$. plantarum by sequencing. Most of the ribotyping-identified isolates showed to be $L b$. plantarum (14 strains). These were grouped in 10 ribogroups (with isolates belonging to the same ribogroup showing similarity coefficients higher than 0.93 ) by using the RiboPrinter's proprietary software. The other 4 isolates were identified as Lb. brevis $(\mathrm{n}=3)$ and Lb. paracasei $(\mathrm{n}=11)$. Lactobacillus brevis strains were each assigned to a different ribogroup.

Table 1. Counts (mean $\pm \mathrm{SD}$ ) of the different microbial groups $\left(\log _{10} \mathrm{cfu} / \mathrm{g}\right)$ in Oaxaca raw milk cheese ${ }^{1}$

\begin{tabular}{lcccc}
\hline AMB & LAB & M and Y & Coliform & Escherichia coli \\
\hline $7.63 \pm 0.76$ & $6.52 \pm 0.85$ & $4.82 \pm 2.52$ & $4.08 \pm 1.41$ & $3.61 \pm 1.21$ \\
\hline${ }^{1} \mathrm{AMB}=$ aerobic mesophilic bacteria; & LAB $=$ lactic acid bacteria; & M and Y = molds and yeasts.
\end{tabular}




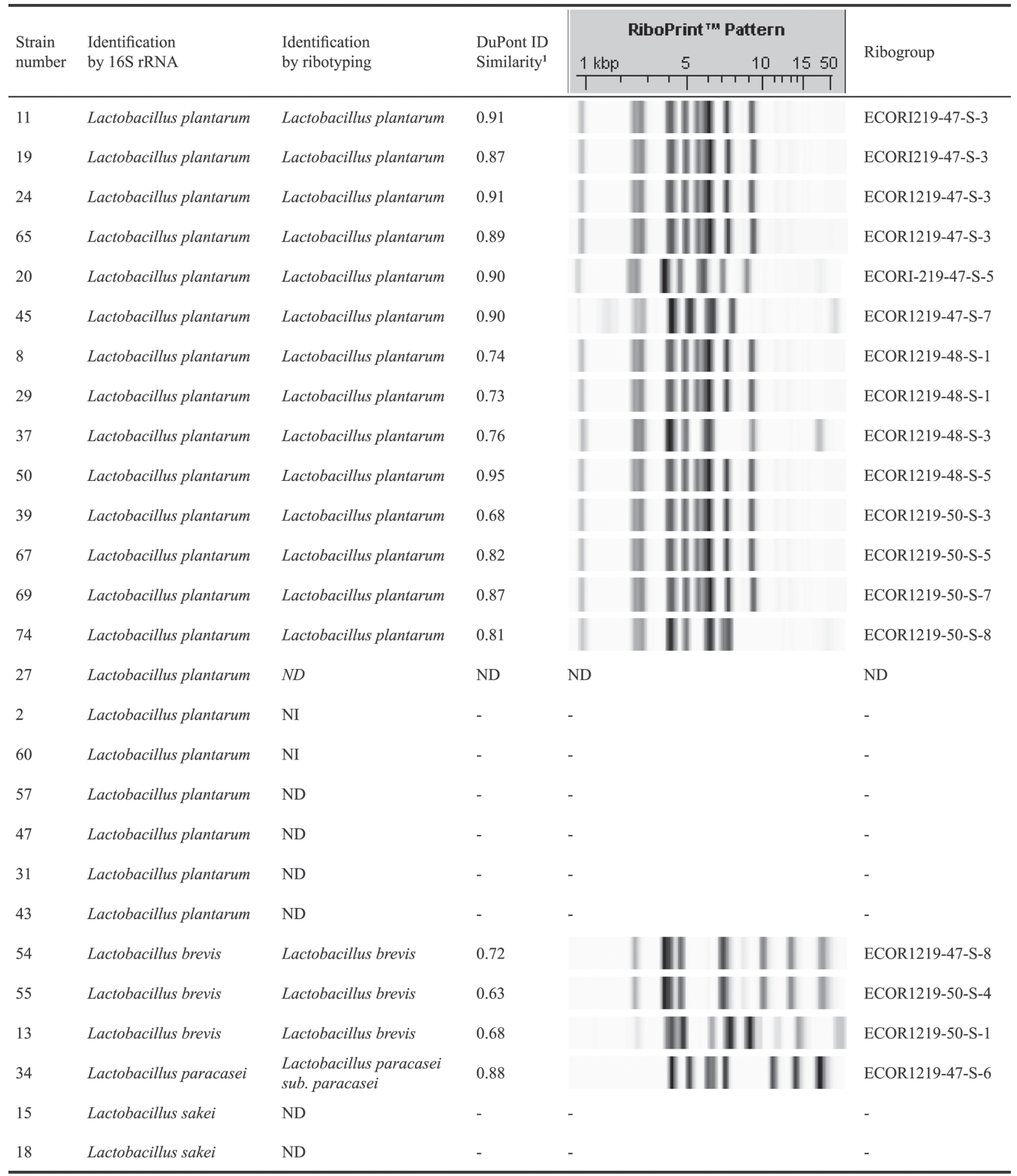

Figure 1. Identification and restriction endonuclease EcoRI ribogroup of Lactobacillus isolated from Oaxaca cheese by ribotyping and 16S rRNA sequences. ND = not determined/not subjected to identification by ribotyping; NI = not identified by ribotyping. ${ }^{1}$ DuPont ID similarity $=$ a similarity measure to assign the name of the genus, species, and specific subgroup. 


\section{Phenotypic Characterization}

Results of antibiotic sensitivity assays (resistance) are shown in Table 2. All isolates showed resistance against at least 3 antibiotics (resistance index of 0.15 ). The highest resistance index was 0.5 (resistance to 10 antibiotics; strain 57). A total of $63 \%$ of isolates showed resistance indexes equal or higher than 0.3. All lactobacilli were found to be resistant to metronidazole (group IV), but, on the other hand, were sensitive to the amoxicillin/clavulanic acid combination (group I); doxycycline (group II); gentamicin, streptomycin, clindamycin, and neomycin (group III); and polymyxin B (group V).
When resistance to antibiotics in group I ( $\beta$-lactam) was tested for, strains showed less resistance to ampicillin (11\% of strains were resistant) and more resistance to cefoxitin and cefsulodin ( 85 and $81 \%$ of the strains, respectively). Remarkably, some strains resistant to ampicillin and penicillin $\mathrm{G}$ (4 and 10 out of 27, respectively) were sensitive to the combination of amoxicillin and the $\beta$-lactamase inhibitor clavulanic acid. Regarding antimicrobials in group II (non- $\beta$-lactam), twothirds of the strains were resistant to vancomycin and only one strain was resistant to bacitracin, but all were well sensitive to doxycycline.

The highest prevalence of sensitivity was observed for group III antibiotics, with most of them being ami-

Table 2. Antibiotic resistance and antimicrobial activity of Lactobacillus spp. isolated from Oaxaca cheese

\begin{tabular}{|c|c|c|c|c|c|c|}
\hline \multirow[b]{2}{*}{ Strain number (ribogroup) } & \multirow[b]{2}{*}{ Antibiotic resistance ${ }^{2}$} & \multirow[b]{2}{*}{$\mathrm{RI}^{3}$} & \multicolumn{4}{|c|}{ Antimicrobial activity ${ }^{4}$} \\
\hline & & & $\begin{array}{l}\text { Staphylococcus } \\
\text { aureus } \mathrm{S} 13\end{array}$ & $\begin{array}{l}\text { Staphylococcus } \\
\text { aureus } 5192\end{array}$ & $\begin{array}{l}\text { Bacillus } \\
\text { cereus }\end{array}$ & $\begin{array}{l}\text { Listeria } \\
\text { innocua }\end{array}$ \\
\hline \multicolumn{7}{|l|}{ Lactobacillus plantarum } \\
\hline $11(47-\mathrm{s}-3)$ & Met, Na, Stx & 0.15 & - & - & - & - \\
\hline $19(47-\mathrm{s}-3)$ & B, Cfs, Met & 0.15 & - & + & + & + \\
\hline 24 (47-s-3) & Cfs, Fox, Met, Nor, Tmp, Va & 0.30 & + & + & + & + \\
\hline $65(47-\mathrm{s}-3)$ & Cfs, Met, K, Na, Va & 0.25 & - & + & + & + \\
\hline $20(47-\mathrm{s}-5)$ & $\mathrm{Am}, \mathrm{Met}, \mathrm{Na}$ & 0.15 & + & + & - & + \\
\hline $45(47-\mathrm{s}-7)$ & Fox, Met, Nor, P, Te & 0.25 & + & + & + & + \\
\hline $8(48-\mathrm{s}-1)$ & Cfs, Fox, Met, Na, P & 0.25 & - & - & - & - \\
\hline $29(48-\mathrm{s}-1)$ & Cfs, Fox, Met, Na, Nor, Va & 0.30 & + & + & + & + \\
\hline $37(48-\mathrm{s}-3)$ & Cfs, Fox, Met, Na, Nor, Va & 0.30 & + & + & + & + \\
\hline $50(48-\mathrm{s}-5)$ & Cfs, Fox, Met, Na, Nor, Tmp, Va & 0.35 & + & ++ & + & + \\
\hline $39(50-\mathrm{s}-3)$ & Cfs, Fox, Met, Na, Nor & 0.25 & - & - & - & + \\
\hline $67(50-\mathrm{s}-5)$ & Cfs, Met, Na, Va & 0.20 & + & + & + & + \\
\hline $69(50-\mathrm{s}-7)$ & Cfs, Fox, Met, Na, Nor, Va & 0.30 & + & + & + & + \\
\hline $74(50-\mathrm{s}-8)$ & Am, Fox, Met, Na, Nor, P & 0.30 & - & - & + & + \\
\hline $27(\mathrm{ND})$ & Cfs, Fox, Met, Na, Nor, Va & 0.35 & + & - & + & + \\
\hline $2(\mathrm{NI})$ & Cfs, Fox, Met, Nor, Tmp, Va & 0.35 & - & - & - & - \\
\hline $60(\mathrm{NI})$ & Cfs, Fox, Met, Na, Nor, Te, P, Va & 0.40 & - & - & - & - \\
\hline $57(\mathrm{ND})$ & $\begin{array}{l}\text { Am, Cfs, Fox, Met, Na, Nor, P, Stx, } \\
\text { Tmp, Va }\end{array}$ & 0.50 & - & - & - & - \\
\hline $47(\mathrm{ND})$ & $\mathrm{Am}, \mathrm{Met}, \mathrm{Te}$ & 0.15 & - & + & + & + \\
\hline 31 (ND) & Cfs, Fox, Met, Na, Stx, Va & 0.30 & + & + & - & + \\
\hline 43 (ND) & Cfs, Fox, Met, Na, Nor, P, Va & 0.35 & - & - & - & - \\
\hline \multicolumn{7}{|l|}{ Lactobacillus brevis } \\
\hline $54(47-\mathrm{s}-8)$ & Cfs, Fox, Met, Na, Nor, P, Va & 0.35 & ++ & ++ & + & + \\
\hline $55(50-\mathrm{s}-4)$ & Cfs, Fox, Met, Na, Nor, P, Va & 0.35 & - & - & - & - \\
\hline $13(50-\mathrm{s}-1)$ & Cfs, Fox, Met, Na, Nor, P, Va & 0.35 & - & - & - & - \\
\hline \multicolumn{7}{|c|}{ Lactobacillus paracasei ssp. paracasei } \\
\hline $34(47-\mathrm{s}-6)$ & Cfs, Fox, Met, Na, P & 0.25 & - & - & + & - \\
\hline \multicolumn{7}{|l|}{ Lactobacillus sakei } \\
\hline $15(\mathrm{ND})$ & Cfs, Fox, Met, Na, Stx, Va & 0.30 & - & - & - & - \\
\hline $18(\mathrm{ND})$ & Cfs, Fox, Met, Na, Nor, Stx, Tmp, Va & 0.40 & - & + & + & ++ \\
\hline
\end{tabular}

${ }^{1} \mathrm{ND}=$ not determined/not subjected to identification by ribotyping; NI = not identified by ribotyping (ribogroup).

${ }^{2}$ Antibiotic abbreviations (the number in parentheses indicates the respective group): Am = ampicillin (I); B = bacitracin (II); Cfs = cefsulodin (I); Fox (I) = cefoxitin; K (III) = kanamycin; Met (IV) = metronidazole; Na (IV) = nalidixic acid; Nor (IV) = norfloxacin; P (I) = penicillin Stx $(\mathrm{V})=$ trimethoprim-sulfamethoxazole; Te $(\mathrm{III})=$ tetracycline; Tmp $(\mathrm{V})=$ trimethoprim; Va $(\mathrm{II})=$ vancomycin. The antibiotic groups are as follows: I = $\beta$-lactams; II = non- $\beta$-lactams cell wall; III = inhibit protein or mRNA synthesis; IV = DNA gyrase or DNA synthesis, or both; $\mathrm{V}=$ antimetabolites or cell membrane disruption.

${ }^{3}$ Resistance index.

${ }^{4}$ Antimicrobial activity against the pathogens tested is marked as $-=$ no activity detected, $+=$ inhibition zone $\geq 1 \mathrm{~mm}$, and $++=$ inhibition zone $\geq 2 \mathrm{~mm}$. 
noglycosides. All strains were sensitive to clindamycin, streptomycin, and neomycin. Moreover, most of them were equally sensitive to tetracycline and kanamycin. In the opposite way, the highest prevalence of resistance among the isolates was shown in relation to certain antimicrobial agents in group IV. Strains showed significant resistance to metronidazole (100\%), the quinolone nalidixic acid (81\%), and to norfloxacin (63\%), the new-generation fluoroquinolone. As for group V, $20 \%$ of the strains were resistant to trimethoprim alone or in combination with sulfamethoxazole, but, on the other hand, all strains were sensitive to polymyxin B, an effective antibacterial cell membrane disruptor.

The results of the antimicrobial activity test of strains are also shown in Table 2. Two-thirds of the Lactobacillus strains showed antimicrobial activity against at least one of the tested strains, especially against $L$. innocua (60\%). In addition, 8 out of 27 showed activity against all of them. Lactobacilli strains 50 and 54 showed a relatively strong activity against Staph. aureus.

Results on the selected phenotypic characteristics, those of interest in relation to starter culture selection, as determined by using the Vitek gram-positive identification system, are shown in Table 3 (not all the characteristics are shown for brevity). All strains were able to grow in 10 and $40 \%$ bile salt solutions. All but 3 strains showed positive growth in $6 \% \mathrm{NaCl}$ broth. Moreover, only one strain showed arginine decarboxylase activity. Furthermore, all strains tested were able to reduce the $\mathrm{pH}$ of milk from 0.3 to $0.5 \mathrm{U}$ after $6 \mathrm{~h}$ of incubation (Table 3) and to reduce the $\mathrm{pH}$ by approximately $1 \mathrm{U}$ after $24 \mathrm{~h}$. Finally, all strains were capable of growing at 15 and $45^{\circ} \mathrm{C}$ (data not shown in tables).

\section{DISCUSSION}

\section{Microbiological Counts and Genetic Identification}

Aerobic mesophilic and psychrotrophic bacteria as well as LAB counts were found to be consistent with those reported in other studies on fresh raw milk pasta filata cheeses (Çetinkaya and Soyutemiz, 2006; Mucchetti et al., 2008). Coliform, E. coli, and mold and yeast counts presented high standard deviations relative to the mean values. There is not a simple and clear explanation for this lack of uniformity. However, at least partially, it reflects variations in the hygienic conditions in the different cheese-making plants used in this study.

As expected, Oaxaca cheese showed high LAB counts, with almost half of them being considered as lactobacilli. During pasta filata cheese making, the LAB microbiota cause a rapid acidification of curd and become predominant; afterward, although the heating of the curd during kneading and stretching results in a reduction in the microbial population, LAB appears to remain the predominant group (Çetinkaya and Soyutemiz, 2006). A predominance of LAB with a particularly high presence of lactobacilli populations has been found by other authors in pasta filata cheeses (Papademas and Robinson, 2000; Gobbetti et al., 2002; Piraino et al., 2005), and other cheeses with a curd acidified to similar $\mathrm{pH}$ values (around 5.2), such as Cheddar, Domiati, or Halloumi cheeses (Haddadin, 1986; McSweeney et al., 1993; Papademas and Robinson, 2000).

In this study, good concordance existed between sequencing of the $16 \mathrm{~S}$ rRNA and ribotyping for the results of genetic identification of the lactobacilli isolates tested. However, the ribotyping method gave additional information on strain discrimination within species by means of the adscription of strains to ribogroups. Several isolates presented identical ribopatterns (i.e., 4 isolates belonged to the 47 -s-3 ribogroup and 2 isolates to 48-s-1). However, the isolates in the same ribogroup presented different phenotypic behavior. This leads to the suggestion that isolates in the same ribogroup could be a single strain showing different gene expression.

\section{Phenotypic Characterization}

The results of antimicrobial resistance found in this study generally agree with reports indicating that LAB strains are commonly resistant to principal types of antibiotics such as $\beta$-lactam, cephalosporins, aminoglycosides, quinolones, imidazole, nitrofurantoin, and fluoroquinolones (Halami et al., 2000). Transfer of resistance to antimicrobial compounds is an essential mechanism of adaptation of bacteria to survive in specific environments (Davies, 1997). Increasing evidence indicates that an overuse of antibiotics in the treatment and prophylaxis of bacterial infections of food-producing animals could be the principal factor regarding the bacterial resistance to such medicines (Tollefson and Karp, 2004). This fact could explain the high levels of resistance shown by the strains examined with respect to many of the antibiotics investigated.

With respect to group I ( $\beta$-lactam) antibiotics, Zarazaga et al. (1999) found a high portion of Lb. plantarum strains to be resistant to penicillin. $\beta$-Lactamases, a family of resistance enzymes, which includes penicillinases and cephalosporinases, are involved in resistance to $\beta$-lactam antibiotics (Bush et al., 1995). Our results suggest the presence of these enzymes in some of the lactobacilli strains.

With regard to antibiotics in group II (non- $\beta$-lactam), the resistance against bacitracin has been related to strains isolated from cattle where this compound was used as a growth-promoting agent (Dutta and Devri- 
Table 3. Selected characteristics obtained from the Vitek gram-positive identification (GPI) system (bioMérieux, Marcy l'Étoile, France) and $\mathrm{pH}$ decrement at different incubation times (h) of Lactobacillus spp. isolated from Oaxaca cheese

\begin{tabular}{|c|c|c|c|c|c|c|c|c|}
\hline \multirow[b]{2}{*}{ Strain number } & \multirow[b]{2}{*}{ Ribogroup $^{1}$} & \multicolumn{4}{|c|}{ Vitek GPI system $^{2}$} & \multicolumn{3}{|c|}{$\mathrm{pH}$ decrement ${ }^{3}$} \\
\hline & & $6 \mathrm{NaCl}$ & $10 \mathrm{~B}$ & $40 \mathrm{~B}$ & $\mathrm{ARG}$ & $6 \mathrm{~h}$ & $12 \mathrm{~h}$ & $24 \mathrm{~h}$ \\
\hline 11 & $47-\mathrm{s}-3$ & + & + & + & - & 0.37 & 0.68 & 0.99 \\
\hline 19 & $47-\mathrm{s}-3$ & + & + & + & - & 0.40 & 0.64 & 0.96 \\
\hline 24 & $47-\mathrm{s}-3$ & + & + & + & - & 0.38 & 0.71 & 0.98 \\
\hline 65 & $47-\mathrm{s}-3$ & + & + & + & - & 0.35 & 0.69 & 1.04 \\
\hline 8 & $48-\mathrm{s}-1$ & + & + & + & - & 0.40 & 0.63 & 0.99 \\
\hline 29 & $48-\mathrm{s}-1$ & + & + & + & - & 0.39 & 0.64 & 0.98 \\
\hline 37 & $48-\mathrm{s}-3$ & + & + & + & - & 0.52 & 0.71 & 0.98 \\
\hline 50 & $48-\mathrm{s}-5$ & + & + & + & - & 0.50 & 0.69 & 0.96 \\
\hline 39 & $50-\mathrm{s}-3$ & + & + & + & - & 0.39 & 0.69 & 0.97 \\
\hline 67 & $50-\mathrm{s}-5$ & + & + & + & - & 0.50 & 0.75 & 1.20 \\
\hline 69 & $50-\mathrm{s}-7$ & + & + & + & - & 0.46 & 0.70 & 1.15 \\
\hline 47 & ND & + & + & + & - & 0.37 & 0.61 & 0.90 \\
\hline 31 & ND & + & + & + & - & 0.30 & 0.77 & 1.45 \\
\hline 43 & ND & - & + & + & - & 0.38 & 0.60 & 0.90 \\
\hline \multicolumn{9}{|c|}{ Lactobacillus brevis } \\
\hline 54 & $47-\mathrm{s}-8$ & + & + & + & - & 0.36 & 0.65 & 0.93 \\
\hline 55 & $50-\mathrm{s}-4$ & + & + & + & - & 0.40 & 0.70 & 0.99 \\
\hline 13 & $50-\mathrm{s}-1$ & + & + & + & + & 0.48 & 0.80 & 1.23 \\
\hline \multicolumn{9}{|c|}{ Lactobacillus paracasei ssp. paracasei } \\
\hline 34 & $(47-\mathrm{s}-6)$ & + & + & + & - & 0.28 & 0.34 & 0.46 \\
\hline \multicolumn{9}{|c|}{ Lactobacillus sakei } \\
\hline 15 & ND & + & + & + & - & 0.42 & 0.71 & 0.96 \\
\hline 18 & ND & + & + & + & - & 0.40 & 0.70 & 0.97 \\
\hline
\end{tabular}

${ }^{1} \mathrm{ND}=$ not determined/not subjected to identification by ribotyping; $\mathrm{NI}=$ not identified by ribotyping (ribogroup).

${ }^{2} 6 \mathrm{NaCl}=$ ability to grow in $6 \% \mathrm{NaCl}$ solution; $10 \mathrm{~B}$ and $40 \mathrm{~B}=$ ability to grow in 10 and $40 \%$ bile solution, respectively; ARG = arginine decarboxylase activity.

${ }^{3}$ The value expressed is the decrease in $\mathrm{pH}$ with respect to the initial $\mathrm{pH}$ of milk (6.05); the standard deviations of replicates were always lower than 0.05 .

ese, 1981). In this study, lactobacilli generally showed resistance to the glycopeptide vancomycin, which is an antibiotic used in clinical situations when all others fail. This is certainly not new and agrees with the results reported by De Fabrizio et al. (1994). Resistance to vancomycin seems to be transferable; for example, the curing of vancomycin resistance from a Lactobacillus acidophilus strain by removal of plasmids has been reported (Vescovo et al., 1982).

A significantly high sensitivity (sensitivity of $100 \%$ or near to) was observed in antimicrobials belonging to group III (protein synthesis inhibitors), such as neomycin, clindamycin, kanamycin, streptomycin, and gentamicin, which bind to small or large ribosomal subunits. High resistance to aminoglycoside antibiotics seems to be considered to be intrinsic in the Lactobacillus genus and is attributed to the absence of cytochrome-mediated electron transport, which mediates drug uptake (Monteagudo-Mera et al., 2012). However, these results do not agree with those obtained by Curragh and Col- lins (1992), who observed a high spontaneous mutation rate to streptomycin and kanamycin resistance.

The observed resistance among lactobacilli to the synthetic and wide-spectrum quinolones (group IV) nalidixic acid and the new-generation fluoroquinolone norfloxacin has already been mentioned (Halami et al., 2000). On the other hand, the observed resistance to metronidazole agrees with other studies (Charteris et al., 1998; Katla et al., 2001). This resistance could be due to the absence of hydrogenase activity (Church et al., 1996).

Lactobacillus spp. have decreased sensitivity to trimethoprim (group V) because of a trimethopriminsensitive dihydrofolate reductase (Huovinen, 1987). In concordance with this, 26 Lactococcus lactis strains isolated from food by Teuber et al. (1999) were resistant to trimethoprim.

Cheeses produced from raw milk or with a starter including LAB resistant to antimicrobials may act as vectors in generating resistance to certain antibiotics in 
bacteria infecting humans (Herrero et al., 1996; Teuber et al., 1999). The use of suitable starter cultures and appropriate substrates, such as pasteurized milk, for food fermentation are among the measures that could hinder the distribution of bacteria spreading resistance. In this context, among the isolates tested, those showing a low resistance index (i.e., $\leq 0.2$ ) could be considered as candidates to be used in starter cultures.

Inhibition of foodborne pathogens by the LAB strains was clearly seen through the tests carried out (Table 2), but the nature of the inhibitory substances was not studied. Lactic acid bacteria are well known to produce antibacterial substances (i.e., organic acids, $\mathrm{H}_{2} \mathrm{O}_{2}$, or bacteriocin-like substances), which can be beneficial for cheese preservation and the prevention of growth of foodborne pathogens (Stiles, 1996; Dunne et al., 2001). No apparent correlation was observed between antibiotic resistance and antimicrobial activity of the isolates tested. However, among the isolates studied, out of the strains showing the lowest antibiotic resistance (index $\leq 0.2$ ), 4 also showed high antimicrobial activity (strain numbers 19, 20, 47, and 67).

Adaptation of LAB to $\mathrm{NaCl}$ allows these microorganisms to grow and survive under the restrictive conditions found in cheese. Studies of salt tolerance of lactobacilli have given contradictory results. Durlu-Ozkaya et al. (2001) and Siezen et al. (2010) found that most Lb. plantarum and (or) paracasei strains isolated from food, cheese included, were not able to grow in 6 to $6.5 \% \mathrm{NaCl}$ solutions. However, Petrovic et al. (2006) reported that all the 43 lactobacilli strains isolated from several fermented foods (mostly cheeses) were tolerant of $\mathrm{NaCl}$ at $6 \%$. In the present study, most of the Lactobacillus spp. isolated from Oaxaca cheese (89\%) and, specifically, all the 4 above-mentioned valuable strains, were able to grow in the presence of $\mathrm{NaCl}$ at $6 \%$.

The totality of lactobacilli isolated in the present study showed bile-salt resistance (at concentrations of 10 and 40\%). In agreement with this, a considerable number of LAB strains have shown bile-salt resistance in other studies (Erkkilä and Petäjä, 2000; Moser and Savage, 2001). This property would confer LAB, together with acid resistance, the ability to reach the human intestine, which is a critical requirement for potential probiotic strains for use as cultures in fermented food (Ammor and Mayo, 2007). Furthermore, LAB cultures should be composed of amine-negative carboxylase strains. In this context, the activity of arginine decarboxylase appears to be a good indicator of the ability of LAB for generating biogenic amines in cheese (Schneller et al., 1997). Advantageously, all the strains tested in the present study except one $[L b$. brevis (strain number 13)] were negative for arginine decarboxylase activity.
Finally, the good ability of LAB to produce lactic acid is one of most important characteristic for LAB strains to be used in starter cultures for the manufacture of unripened pasta filata cheeses (Coppola et al., 1990; Bernardeau et al., 2008). However, a potential culture should not only include LAB strains with high acid-producing activity, responsible for rapid curd acidification. Appropriate lactobacilli strains could, thus, be used as adjunct cultures (those added to cheese for purposes other than acid formation), to contribute to the elimination of defects by adventitious nonstarter LAB and improvement in cheese flavor (Wouters et al., 2002). In the present study, all the lactobacilli strains tested showed poor acid-producing ability in milk for the first $12 \mathrm{~h}$ of incubation. After $24 \mathrm{~h}$, the strains were able to reduce the $\mathrm{pH}$ by approximately $1 \mathrm{U}$. These results agree with the low acidification ability found for lactobacilli by Cogan et al. (1997) and Morea et al. (1998). Moreover, Herreros et al. (2003) found that the acidification developed by strains of $L b$. plantarum and $L b$. brevis isolated from cheese was even lower.

\section{CONCLUSIONS}

Lactobacilli are an important part of the microbiota of raw milk Oaxaca cheese. Significant divergences in relevant characteristics among the lactobacilli isolated were observed, suggesting considerable intraspecies variability. According to the strains' characteristics studied, 4 strains could be selected to be used in an adjunct culture, together with a starter culture with high acidifying power, for the manufacture of pasteurizedmilk Oaxaca cheese: Lb. plantarum, strain numbers 19, 20, 47, and 67. All 4 strains showed an antibiotic resistance index equal to or lower than 0.20 , antimicrobial activity against the enterotoxigenic Staph. aureus strain, and L. innocua, amine-negative decarboxylase activity, and resistance to $\mathrm{NaCl}$ and bile salt solutions.

\section{ACKNOWLEDGMENTS}

The authors thank the Mexican Government Programa de Mejoramiento del Profesorado-Secretaría de Educación Pública (PROMEP-SEP) program (20052008) for their financial support. We also thank Donal J. Savage (Associate of the Institute of Linguists, León, Spain) for his help in revising the grammatical structure of this article. Finally, we acknowledge support from the Laboratory of Instrumental Analysis from the University of León (Spain) where the DNA sequencing analysis was carried out.

\section{REFERENCES}

Aguilar-Uscanga, B. R., M. Montero-Lagunes, J. De la Cruz, J. R. Solis-Pacheco, and H. S. García. 2006. Using fermented cheese 
whey to reduce acidification time of Oaxaca cheese. Agrociencia 40:569-575.

Ammor, M. S., and B. Mayo. 2007. Selection criteria for lactic acid bacteria to be used as functional starter cultures in dry sausage production: An update. Meat Sci. 76:138-146.

Beresford, T. P., N. A. Fitzsimons, N. L. Brennan, and T. M. Cogan. 2001. Recent advances in cheese microbiology. Int. Dairy J. 11:259-274.

Bernardeau, M., J. P. Vernoux, S. Henri-Dubernet, and M. Guéguen. 2008. Safety assessment of dairy microorganisms: The Lactobacillus genus. Int. J. Food Microbiol. 126:278-285.

Bush, L. M., J. Calmon, and C. C. Johnson. 1995. Newer penicillins and beta-lactamase inhibitors. Infect. Dis. Clin. North Am. 9:653-686

Caro, I., S. Soto, M. J. Franco, M. Meza-Nieto, R. H. Alfaro-Rodríguez, and J. Mateo. 2011. Composition, yield and functionality of reduced-fat Oaxaca cheese: Effects of the use of skim milk or a dry milk protein concentrate. J. Dairy Sci. 94:580-588.

Çetinkaya, F., and G. E. Soyutemiz. 2006. Microbiological and chemical changes throughout the manufacture and ripening of Kashar: A traditional Turkish cheese. Turk. J. Vet. Anim. Sci. 30:397-404.

Charteris, W. P., P. M. Kelly, L. Morelli, and J. K. Collins. 1998. Antibiotic susceptibility of potentially probiotic Lactobacillus species. J. Food Prot. 61:1636-1643.

Church, D. L., R. D. Bryant, V. Sim, and E. J. Laishley. 1996. Metronidazole susceptibility and the presence of hydrogenase in pathogenic bacteria. Anaerobe 2:147-153.

Cogan, T. M., M. Barbosa, E. Beuvier, B. Bianchi-Salvadori, P. S. Cocconcelli, I. Fernandes, J. Gomez, R. Gomez, G. Kalantzopoulos, A. Ledda, M. Medina, M. C. Rea, and E. Rodríguez. 1997. Characterization of the lactic acid bacteria in artisanal dairy products. J. Dairy Res. 64:409-421.

Coppola, S., F. Villani, R. Coppola, and E. Parente. 1990. Comparison of different starter systems for water-buffalo Mozzarella cheese manufacture. Lait 70:411-423.

Curragh, H. J., and M. A. Collins. 1992. High-levels of spontaneous drug resistance in Lactobacillus. J. Appl. Bacteriol. 73:31-36.

Davies, J. E. 1997. Origins, acquisition and dissemination of antibiotic resistance determinants. Ciba Found. Symp. 207:15-27.

De Fabrizio, S. V., J. L. Parada, and R. A. Ledford. 1994. Antibiotic resistance of Lactococcus lactis - An approach of genetic determinants locations through a model system. Microbiol. Aliments Nutr. 12:307-315.

de los Ángeles Colín-Cruz, M., O. Dublán-García, A. Espinoza-Ortega, and A. Dominguez-Lopez. 2012. The effect of varying fat content on the microstructure of Oaxaca cheese, a typical pasta filata cheese. Int. J. Dairy Technol. 65:71-80.

De Oca-Flores, E. M., O. A. Castelán-Ortega, J. G. Estrada-Flores, and A. Espinoza-Ortega. 2009. Oaxaca cheese: Manufacture process and physicochemical characteristics. Int. J. Dairy Technol. 62:535-540.

Domínguez-López, A., A. Villanueva-Carvajal, C. M. Arriaga-Jordán, and A. Espinoza-Ortega. 2011. Artisan-made and traditional foods: The Oaxaca fresh cheese as study case in central Mexico. Estud. Soc. 19:166-193.

Dunne, C., L. O'Mahony, L. Murphy, G. Thornton, D. Morrissey, S. O'Halloran, M. Feeney, S. Flynn, G. Fitzgerald, C. Daly, B. Kiely, G. C. O'Sullivan, F. Shanahan, and J. K. Collins. 2001. In vitro selection criteria for probiotic bacteria of human origin: Correlation with in vivo findings. Am. J. Clin. Nutr. 73:386S-392S.

Durlu-Ozkaya, F., V. Xanthopoulos, N. Tunail, and E. LitopoulouTzanetaki. 2001. Technologically important properties of lactic acid bacteria isolates from Beyaz cheese made from raw ewes' milk. J. Appl. Microbiol. 91:861-870.

Dutta, G. N., and L. A. Devriese. 1981. Sensitivity and resistance to growth promoting agents in animal lactobacilli. J. Appl. Bacteriol. 51:283-288.

Erkkilä, S., and E. Petäjä. 2000. Screening of commercial meat starter cultures at low $\mathrm{pH}$ and in the presence of bile salts for potential probiotic use. Meat Sci. 55:297-300.
Gobbetti, M., M. Morea, F. Baruzzi, M. R. Corbo, A. Matarante, T. Considine, R. Di Cagno, T. Guinee, and P. F. Fox. 2002. Microbiological, compositional, biochemical and textural characterization of Caciocavallo Pugliese cheese during ripening. Int. Dairy J. $12: 511-523$.

González, L., H. Sandoval, N. Sacristán, J. M. Castro, J. M. Fresno, and M. E. Tornadijo. 2007. Identification of lactic acid bacteria isolated from Genestoso cheese throughout ripening and study of their antimicrobial activity. Food Contr. 18:716-722.

Haddadin, M. S. Y. 1986. Microbiology of white-brined cheeses. Pages 67-89 in Developments in Food Microbiology. R. K. Robinson, ed. Elsevier Applied Science, London, UK.

Halami, P. M., A. Chandrashekar, and K. Nand. 2000. Lactobacillus farciminis $\mathrm{MD}$, a newer strain with potential for bacteriocin and antibiotic assay. Lett. Appl. Microbiol. 30:197-202.

Harrigan, W. F. 1998. Laboratory Methods in Food Microbiology. 3rd rev. ed. Academic Press, London, UK.

Herrero, M., B. Mayo, B. González, and J. E. Suárez. 1996. Evaluation of technologically important traits in lactic acid bacteria isolated from spontaneous fermentations. J. Appl. Bacteriol. 81:565-570.

Herreros, M. A., J. M. Fresno, M. J. González Prieto, and M. E. Tornadijo. 2003. Technological characterization of lactic acid bacteria isolated from Armada cheese (a Spanish goats' milk cheese). Int. Dairy J. 13:469-479.

Huovinen, P. 1987. Trimethoprim resistance. Antimicrob. Agents Chemother. 31:1451-1456.

IDF (International Dairy Federation). 1995a. Milk and milk products - Guidance on methods of sampling. Standard 50C. IDF, Brussels, Belgium.

IDF (International Dairy Federation). 1995b. IDF guideline-Determination of acidifying activity of dairy cultures. Bulletin IDF 306. IDF, Brussels, Belgium, pp. 34-36.

IDF (International Dairy Federation). 1996. Preparation of samples and dilutions for microbiological examination. Standard 122C. IDF, Brussels, Belgium.

Katla, A.-K., H. Kruse, G. Johnsen, and H. Herikstad. 2001. Antimicrobial susceptibility of starter culture bacteria used in Norwegian dairy products. Int. J. Food Microbiol. 67:147-152.

Khalid, N. M., and E. H. Marth. 1990. Lactobacilli-Their enzymes and role in ripening and spoilage of cheese: A review. J. Dairy Sci. 73:2669-2684.

Kongo, J. M., A. J. Ho, F. X. Malcata, and M. Wiedmann. 2007. Characterization of dominant lactic acid bacteria isolated from São Jorge cheese, using biochemical and ribotyping methods. J. Appl. Microbiol. 103:1838-1844.

Mathur, S., and R. Singh. 2005. Antibiotic resistance in food lactic acid bacteria-A review. Int. J. Food Microbiol. 105:281-295.

McSweeney, P. L. H., P. F. Fox, J. A. Lucey, K. N. Jordan, and T. M. Cogan. 1993. Contribution of the indigenous microflora to the maturation of Cheddar cheese. Int. Dairy J. 3:613-634.

Monteagudo-Mera, A., L. Rodríguez-Aparicio, J. Rúa, H. MartínezBlanco, N. Navasa, M. R. García-Armesto, and M. Á. Ferrero. 2012. In vitro evaluation of physiological probiotic properties of different lactic acid bacteria strains of dairy and human origin. J. Funct. Foods 4:531-541

Morea, M., F. Baruzzi, F. Cappa, and P. S. Cocconcelli. 1998. Molecular characterization of the Lactobacillus community in traditional processing of Mozzarella cheese. Int. J. Food Microbiol. 43:53-60.

Moser, S. A., and S. C. Savage. 2001. Bile salt hydrolase activity and resistance to toxicity of conjugated bile salts are unrelated properties in lactobacilli. Appl. Environ. Microbiol. 67:3476-3480.

Mucchetti, G., B. Bonvini, M. C. Remagni, R. Ghiglietti, F. Locci, S. Barzaghi, S. Francolino, A. Perrone, A. Rubiloni, P. Campo, M. Gatti, and D. Carminati. 2008. Influence of cheese-making technology on composition and microbiological characteristics of Vastedda cheese. Food Contr. 19:119-125.

NCCLS (National Committee for Clinical Laboratory Standards). 1997. Performance standards for antimicrobial disk and dilution susceptibility tests: Approved Standard. 6th ed. NCCLS Document M2-A6. NCCLS, Wayne, PA. 
Papademas, P., and R. K. Robinson. 2000. A comparison of the chemical, microbiological and sensory characteristics of bovine and ovine Halloumi cheese. Int. Dairy J. 10:761-768.

Petrovic, T., M. Niksic, and F. Bringel. 2006. Strain typing with ISLpl1 in lactobacilli. FEMS Microbiol. Lett. 255:1-10.

Piraino, P., T. Zotta, A. Ricciardi, and P. Parente. 2005. Discrimination of commercial Caciocavallo cheeses on the basis of the diversity of lactic microflora and primary proteolysis. Int. Dairy J. $15: 1138-1149$

Relman, D. A. 1993. Universal bacterial 16 S rDNA amplification and sequencing. Pages 489-495 in Diagnostic Molecular Microbiology: Principles and Applications. D. H. Pershing, T. F. Smith, F. C Tenover, and T. J. White, ed. American Society for Microbiology, Washington, DC

Sánchez, I., S. Seseña, J. M. Poveda, L. Cabezas, and L. Palop. 2005. Phenotypic and genotypic characterization of lactobacilli isolated from Spanish goat cheeses. Int. J. Food Microbiol. 102:355-362.

Schneller, R., P. Good, and M. Jenny. 1997. Influence of pasteurised milk, raw milk and different ripening cultures on biogenic amine concentrations in semi-soft cheeses during ripening. Eur. Food Res. Technol. 204:265-272.

Shahani, K. M., J. R. Vakil, and R. Kilara. 1976. Natural antibiotic activity of Lactobacillus acidophilus and Lactobacillus bulgaricus. I. Cultural conditions for the production of antibiosis. Cult. Dairy Prod. J. 11:14-17.

Siezen, R. J., V. A. Tzeneva, A. Castioni, M. Wels, H. T. K. Phan, J. L. W. Rademaker, M. J. C. Starrenburg, M. Kleerebezem, D.
Molenaar, and J. E. T. van Hylckama Vlieg. 2010. Phenotypic and genomic diversity of Lactobacillus plantarum strains isolated from various environmental niches. Environ. Microbiol. 12:758-773.

Stiles, M. E. 1996. Biopreservation by lactic acid bacteria. Antonie van Leeuwenhoek 70:331-345.

Teuber, M., L. Meile, and F. Schwarz. 1999. Acquired antibiotic resistance in lactic acid bacteria from food. Antonie van Leeuwenhoek $76: 115-137$.

Tollefson, L., and B. E. Karp. 2004. Human health impact from antimicrobial use in food animals. Med. Mal. Infect. 34:514-521.

Vescovo, M., L. Morelli, and V. Bottazzi. 1982. Drug resistance plasmids in Lactobacillus acidophilus and Lactobacillus reuteri. Appl. Environ. Microbiol. 43:50-56.

Villanueva-Carvajal, A., M. Esteban-Chávez, A. Espinoza-Ortega, C. M. Arriaga-Jordán, and A. Dominguez-Lopez. 2012. Oaxaca cheese: Flavour, texture and their interaction in a Mexican traditional pasta filata type cheese. CyTA J. Food 10:63-70.

Wouters, J. T. M., E. H. E. Ayad, J. Hugenholtz, and G. Smit. 2002 Microbes from raw milk for fermented dairy products. Int. Dairy J. 12:91-109.

Zarazaga, M., Y. Sáenz, A. Portillo, C. Tenorio, R. F. Ruiz-Larrea, R. Del Campo, F. Baquero, and C. Torres. 1999. In vitro activities of ketolide HMR3647, macrolides, and other antibiotics against Lactobacillus, Leuconostoc, and Pediococcus isolates. Antimicrob. Agents Chemother. 43:3039-3041. 